\title{
HUBUNGAN TINGKAT PENGETAHUAN DAN STATUS PEKERJAAN IBU MENYUSUI DENGAN PEMBERIAN ASI EKSKLUSIF DI KELURAHAN SIMPANG HARU TAHUN 2017
}

\author{
Defi Yulita ${ }^{1}$ \\ AKBID Alifah, Jl. Khatib Sulaiman No. 52B, Padang, 25000, Indonesia \\ Email : defi_knu@yahoo.com
}

\begin{abstract}
ABSTRAK
Pemberian ASI secara eksklusif dapat mencegah kematian balita sebanyak 13\%. Data Dinas Kesehatan Kota Padang tentang cakupan pemberian ASI tahun 2016 sebanyak 8.101 bayi (74,77 \%), sedangkan cakupan pemberian ASI tahun 2017 yaitu 8.216 bayi $(74,8 \%)$. Data dari Puskesmas Andalas Padang tahun 2016 yaitu 59,84\%, sedangkan tahun 2017 yaitu 59,8\%. Tujuan umum penelitian ini untuk mengetahui Hubungan tingkat pengetahuan dan status pekerjaan ibu menyusui dengan pemberian ASI eksklusif di Kelurahan Simpang Haru tahun 2017. Jenis penelitian deskriptif analitik dengan desain cross sectional dengan populasi ibu yang mempunyai bayi usia $6-12$ bulan berjumlah 60 orang, sampel diambil dengan cara simple random sampling sebanyak 38 orang. Penelitian dilakukan pada tanggal 14 Mei - 25 Oktober 2017. Data ini diperoleh melalui kuesioner yang diisi langsung oleh responden. Pengolahan data dengan komputerisasi di analisis secara univariat dan bivariat uji hipotesis menggunakan uji chi-square $(\alpha=0,05)$. Hasil penelitian didapatkan sebanyak 21 orang $(55,3 \%)$ ibu memiliki tingkat pengetahuan rendah, sebanyak 13 orang $(34,2 \%)$ ibu bekerja dan sebanyak 16 orang $(42,1 \%)$ ibu tidak memberikan ASI Eksklusif. Berdasarkan analisa bivariat ada hubungan antara tingkat pengetahuan dengan pemberian ASI Eksklusif $(\mathrm{p}=0,000)$ dan ada hubungan antara pekerjaan ibu dengan pemberian ASI Eksklusif pada ibu menyusui di Kelurahan Simpang Haru tahun 2017 ( p = 0,036). Dapat disimpulkan ibu dengan pengetahuan rendah dan bekerja cenderung tidak memberikan ASI eksklusif. Diharapkan kepada petugas kesehatan untuk terus memberikan penyuluhan tentang manfaat ASI eksklusif.
\end{abstract}

Kata Kunci : Tingkat pengetahuan, status Pekerjaan dan pemberian ASI eksklusif

\begin{abstract}
Exclusive breastfeeding can prevent under-five mortality by 13\%. Data from the Padang City Health Office regarding the coverage ASI in 2016 were 8,101 babies (74.77\%), while the coverage of breastfeeding in 2017 was 8,216 babies (74.8\%). Data from Padang Andalas Health Center in 2016 was 59.84\%, while in 2017 it was 59.8\%. The general purpose of this study was to determine the relationship between the level of knowledge and employment status of breastfeeding mothers with exclusive breastfeeding in Simpang Haru Village 2017. The type of descriptive analytic study was cross sectional design with a population of mothers with infants aged 6-12 months. 60 people, the sample was taken by simple random sampling as many as 38 people. The study was conducted on 14 May - 25 October 2017. This data was obtained through a questionnaire that was filled directly by the respondent. Data processing with computerization was analyzed by univariate and bivariate hypothesis testing using the chi-square test $(\alpha=0.05)$. The results showed that 21 people (55.3\%) mothers had a low level of knowledge, as many as 13 people (34.2\%) working mothers and as many as 16 people (42.1\%) mothers did not give exclusive breastfeeding. Based on bivariate analysis there is a relationship between the level of knowledge with exclusive breastfeeding $(p=0.000)$ and there is a relationship between the work of mothers with exclusive breastfeeding for breastfeeding mothers in Simpang Haru Village 2017 ( $p=0.036)$. It can be concluded that mothers with low knowledge and work tend not to provide exclusive breastfeeding. It is expected that health workers continue to provide counseling about the benefits of exclusive breastfeeding.
\end{abstract}

Keywords: Level of knowledge, employment status and exclusive breastfeeding 


\section{PENDAHULUAN}

Air Susu Ibu (ASI) merupakan satusatunya makanan tunggal paling sempurna bagi bayi hingga berusia 6 bulan. ASI cukup mengandung seluruh zat gizi yang dibutuhkan bayi. Selain itu, secara alamiah ASI dibekali enzim pencerna susu sehingga organ pencernaan bayi mudah mencerna dan menyerap gizi ASI. Dilain pihak, sistem pencernaan bayi usia dini belum memiliki cukup enzim pencena makanan (Arif, 2009).

Memberikan ASI secara eksklusif mempunyai efek psikologis yang menguntungkan, waktu menyusui kulit bayi akan menempel pada kulit ibu. Kontak kulit yang dini ini akan sangat besar pengaruhnya pada perkembangan bayi kelak. Perasaan aman ini sangat penting untuk membangun dasar kepercayaan bayi (basic sense of trust) yaitu dengan mulai mempercayai orang lain (ibu), maka selanjutnya akan timbul rasa percaya pada diri sendiri (Suradi, 2010).

Efektifitas ASI dalam mengendalikan infeksi dapat dibuktikan dengan berkurangnya kejadian beberapa penyakit spesifik pada bayi yang mendapat ASI dibanding bayi yang mendapat susu formula. Penelitian oleh WHO membuktikan bahwa pemberian ASI sampai usia 2 tahun dapat menurunkan angka kematian anak akibat penyakit diare dan infeksi saluran cerna (Hegar dkk, 2008 )

Pemberian ASI secara eksklusif dapat mencegah kematian balita sebanyak $13 \%$. Pemberian makanan pendamping ASI pada saat dan jumlah yang tepat dapat mencegah kematian balita sebanyak $6 \%$ sehingga pemberian ASI eksklusif selama 6 bulan dilanjutkan dengan pemberian ASI sampai usia $>2$ tahun bersama makanan pendamping ASI yang tepat mencegah kematian balita sebanyak 19\% (Suradi, 2010).

Depkes menargetkan penurunan AKB berkurang dari 248 menjadi 206 per 100.000 kelahiran yang dicapai. Sementara angka harapan hidup berkisar rata-rata 70,6 tahun. Setelah diteliti lebih mendalam ternyata faktor penyebab utama terjadinya kematian pada bayi baru lahir dan balita adalah penurunan angka pemberian Inisiasi Menyusui Dini dan ASI eksklusif. (Hasrimayana, 2009).

Data Dinas Kesehatan Kota Padang tentang cakupan pemberian ASI pada tahun 2016 sebanyak 8.101 bayi $(74,77 \%)$, sedangkan cakupan pemberian ASI pada tahun 2017 yaitu 74,8 \%. Cakupan data pemberian ASI Eksklusif yang didapatkan dari 24 Puskesmas yang ada di Kota Padang ditemukan pemberian ASI eksklusif terendah di Kelurahan Simpang Haru Wilayah Kerja Puskesmas Andalas Padang pada tahun 2016 yaitu 59,84\%, sedangkan pada tahun 2017 59,8 $\%$ (Profil DKK tahun 2016 dan 2017).

Survei awal yang dilakukan melalui wawancara dengan ibu menyusui di Kelurahan Simpang Haru Wilayah Kerja Puskesmas Andalas Padang Padang, ditemui 4 ibu yang tidak memberikan ASI secara eklusif di karenakan ibu bekerja, 1 orang ibu memberikan ASI eklusif sampai 4 bulan saja dengan alasan ASI nya tidak cukup untuk bayinya dan kurangnya pengetahuan ibu tentang pemberian ASI eksklusif. Dan 4 ibu lainya memberikan ASI eksklusif pada bayinya dengan pemberian ASI saja sampai usia 6 bulan dan ada 1 orang ibu yang sampai 2 tahun memberikan ASI pada bayinya dengan makanan tambahan lainnya.

Berdasarkan data tersebut maka peneliti tertarik melakukan penelitian tentang hubungan Tingkat pengetahuan dan status Pekerjaan ibu menyusui dengan pemberian ASI eksklusif di Kelurahan Simpang Haru Wilayah Kerja Puskesmas Andalas Padang tahun 2017.

\section{METODE PENELITIAN}

Jenis penelitian yang digunakan adalah jenis penelitian analitik. Desain penelitian cross sectinal Dimana variable independen (tingkatan pengetahuan dan status pekerjaan ibu menyusui) dan variable dependen (Pemberian ASI Eksklusif) diteliti pada waktu yang bersamaan (Notoatmodjo,2005), Penelitian ini dilakukan di Kelurahan Simpang Haru Wilayah Kerja Puskesmas Andalas Padang, waktu penelitian tanggal $14 \mathrm{Mei}-25$ Oktober 2017.

Populasi dalam penelitian ini adalah ibu yang mempunyai bayi usia $6-12$ bulan di Kelurahan Simpang Haru Wilayah Kerja Puskesmas Andalas Padang Padang yang berjumlah 60 orang. Pengambilan sampel dilakukan dengan cara simple random sampling yang berjumlah 38 orang.

Dengan Kriteria menjadi sampel sebagai berikut : 
a. Orang tua yang mempunyai bayi usia 6 12 bulan di Kelurahan Simpang Haru Wilayah Kerja Puskesmas Andalas Padang Padang

b. Bersedia menjadi Responden

c. Bisa baca tulis

d. Ada ditempat saat penelitian.

e. Kunjungan minimal 2 kali, apabila responden telah ditemui 2 kali dan responden tidak ada di tempat maka responden dianggap gugur.

\section{HASIL}

Tabel 1

Distribusi Frekuensi Responden Berdasarkan Tingkat Pengetahuan Ibu tentang ASI Eksklsif Di Kelurahan Simpang Haru

\begin{tabular}{|c|c|c|}
\hline Tingkat Pengetahuan & f & \multicolumn{2}{|c|}{$\%$} \\
\hline Rendah & 21 & 55,3 \\
\hline Tinggi & 17 & 44,7 \\
\hline Jumlah & $\mathbf{3 8}$ & $\mathbf{1 0 0}$ \\
\hline
\end{tabular}

Berdasarkan hasil penelitian yang telah dilakukan, lebih dari separoh responden sebanyak 21 orang $(55,3 \%)$ memiliki tingkat pengetahuan rendah tentang ASI Eksklusif.

\section{Tabel 2}

Distribusi Frekuensi Responden Berdasarkan Status Pekerjaan Ibu Tentang ASI Eksklsif Di Kelurahan Simpang Haru

\begin{tabular}{|c|c|c|}
\hline Status Pekerjaan & f & \% \\
\hline Bekerja & 13 & 34,2 \\
\hline Tidak Bekerja & 25 & 65,8 \\
\hline Jumlah & $\mathbf{3 8}$ & $\mathbf{1 0 0}$ \\
\hline
\end{tabular}

Berdasarkan hasil penelitian yang telah dilakukan, sebagian kecil responden sebanyak 13 orang $(34,2 \%)$ ibu memiliki pekerjaan.

Tabel 3

Distribusi Frekuensi Responden Berdasarkan Pemberian ASI Eksklusif Di Kelurahan Simpang Haru

\begin{tabular}{|c|c|c|}
\hline $\begin{array}{c}\text { Pemberian ASI } \\
\text { Eksklusif }\end{array}$ & f & \% \\
\hline Tidak ASI Eksklusif & 16 & 42,1 \\
\hline ASI Eksklusif & 22 & 57,9 \\
\hline Jumlah & $\mathbf{3 8}$ & $\mathbf{1 0 0}$ \\
\hline
\end{tabular}

Berdasarkan hasil penelitian yang telah dilakukan, kurang dari separoh responden sebanyak 16 orang $(42,1 \%)$ tidak memberikan ASI Eksklusif.

Tabel 4

\section{Hubungan Tingkat Pengetahuan Ibu Dengan Pemberian ASI Eksklusif Di Kelurahan Simpang Haru}

\begin{tabular}{|c|c|c|c|c|c|c|c|}
\hline \multirow{3}{*}{ No } & \multirow{3}{*}{$\begin{array}{c}\text { Tingkat } \\
\text { Pengeta } \\
\text { huan }\end{array}$} & \multicolumn{4}{|c|}{$\begin{array}{c}\text { Pemberian ASI } \\
\text { Eksklusif }\end{array}$} & \multirow{2}{*}{\multicolumn{2}{|c|}{ Total }} \\
\hline & & \multicolumn{2}{|c|}{$\begin{array}{c}\text { Tidak } \\
\text { Eksklusif }\end{array}$} & \multicolumn{2}{|c|}{$\begin{array}{c}\text { ASI } \\
\text { Eksklusif }\end{array}$} & & \\
\hline & & $\mathrm{N}$ & $\%$ & $\mathrm{~N}$ & $\%$ & $\mathrm{~N}$ & $\%$ \\
\hline 1. & Rendah & 15 & $\begin{array}{c}71 \\
4\end{array}$ & 6 & 28,6 & 21 & 100 \\
\hline \multirow[t]{2}{*}{2.} & Tinggi & 1 & 5,9 & 16 & 94,1 & 17 & 100 \\
\hline & Jumlah & 16 & 42,1 & 22 & 57,9 & 38 & 100 \\
\hline
\end{tabular}

Berdasarkan hasil penelitian yang telah dilakukan dapat dilihat Proporsi responden yang tidak memberikan ASI Eksklusif lebih banyak pada Responden tingkat pengetahuan rendah yaitu 15 orang $(71,4 \%)$ dibandingkan dengan tingkat pengetahuan tinggi 1 orang (5,9 $\%)$. Berdasarkan analisa data dengan mengunakan uji Chi-Square didapatkan nilai $\mathrm{p}$ $=0,000(\mathrm{p}<0,05)$ ini berarti bahwa ada hubungan antara tingkat pengetahuan dengan pemberian ASI Eksklusif.

Tabel 5

Hubungan Status Pekerjaan Dengan Pemberian ASI Eksklusif Di Kelurahan Simpang Haru

\begin{tabular}{|c|c|c|c|c|c|c|c|}
\hline \multirow{3}{*}{$\begin{array}{l}\mathbf{N} \\
\mathbf{0}\end{array}$} & \multirow{3}{*}{$\begin{array}{c}\text { Status } \\
\text { Pekerjaan }\end{array}$} & \multicolumn{4}{|c|}{$\begin{array}{c}\text { Pemberian ASI } \\
\text { Eksklusif }\end{array}$} & \multirow{2}{*}{\multicolumn{2}{|c|}{ Total }} \\
\hline & & \multicolumn{2}{|c|}{$\begin{array}{c}\text { Tidak } \\
\text { ASI } \\
\text { Eksklusif } \\
\end{array}$} & \multicolumn{2}{|c|}{$\begin{array}{c}\text { ASI } \\
\text { Eksklusi } \\
\text { f }\end{array}$} & & \\
\hline & & $\mathrm{N}$ & $\%$ & $\mathrm{~N}$ & $\%$ & $\mathrm{~N}$ & $\%$ \\
\hline 1 & Bekerja & 9 & 69,2 & 4 & $\begin{array}{l}30 \\
, 8\end{array}$ & 8 & $\begin{array}{c}10 \\
0\end{array}$ \\
\hline
\end{tabular}


Volume 2 Nomor 2 P-ISSN : 2597-8594

\begin{tabular}{|c|l|c|c|c|c|c|c|}
\hline \hline 2 & Tidak & 7 & 28,0 & $\begin{array}{c}1 \\
8\end{array}$ & $\begin{array}{c}72 \\
, 0\end{array}$ & 30 & $\begin{array}{c}10 \\
0\end{array}$ \\
\hline & Bekerja & & & $\mathbf{2 2}$ & $\mathbf{5 7 , 9}$ & $\mathbf{3 8}$ & $\mathbf{1 0 0}$ \\
\hline & Jumlah & $\mathbf{1 6}$ & $\mathbf{4 2 , 1}$ & $\mathbf{2 2}$ & \multicolumn{6}{c|}{$\boldsymbol{0 3 6}$}
\end{tabular}

Berdasarkan hasil penelitian yang telah dilakukan, dapat dilihat bahwa proporsi responden yang tidak memberikan ASI Eksklusif lebih banyak pada ibu yang bekerja sebanyak 9 orang $(69,2 \%)$ dibandingkan dengan ibu yang tidak bekera yaitu 7 orang $(28,0 \%)$. Berdasarkan analisa data dengan mengunakan uji Chi-Square didapatkan nilai $\mathrm{p}$ $=0,036(\mathrm{p}<0,05)$ ini berarti bahwa ada hubungan antara pekerjaan dengan pemberian ASI Eksklusif..

\section{PEMBAHASAN}

Berdasarkan tabel 1 dapat dilihat bahwa lebih dari separoh yaitun 21 orang $(55,3 \%)$ memiliki tingkat pengetahuan rendah tentang ASI Eksklusif. Hasil Penelitian ini sama dengan yang dilakukan Dewi (2010) maka dapat terdapat $(56,3 \%)$ responden memiliki tingkat pengetahuan rendah tentang ASI eksklusif di Puskesmas Lubuk Begalung Padang. Rendahnya persentase pengetahuan dapat dilihat dari pendidikan responden memiliki berpendidikan SD dan SMP dapat di lihat dari pengisian kuesioner yang menjawab salah tentang berapa lama ASI perah dapat disimpan dalam lemari es sebanyak 31,5\%.

Berdasarkan tabel 2 dapat dilihat, sebagian kecil responden yaitu 13 orang $(34,2 \%)$ ibu memiliki pekerjaan. Hal ini sesuai dengan pendapat Soetjiningsih (1997) menyatakan bahwa kecenderungan makin banyak ibu-ibu yang tidak memberikan ASI pada bayinya salah satu penyebabnya adalah banyaknya ibu-ibu yang bekerja terutama di kota-kota besar. Ketidakhadiran ibu dirumah dalam jangka waktu tertentu untuk bekerja biasanya akan menimbulkan masalah dalam mengatur waktu karena banyaknya jam kerja dan jarak antara tempat bekerja dengan rumah ibu yang jauh.

Berdasarkan tabel 3 dapat dilihat, kurang dari separoh responden sebanyak 16 orang $(42,1 \%)$ tidak memberikan ASI Eksklusif. Hasil penelitian ini sama dengan penelitian Dewi (2010) maka dapat terdapat $(55,2 \%)$ responden tidak memberikan ASI eksklusif di Puskesmas Lubuk Begalung Padang. Hal ini sesuai dengan pendapat
Soetjiningsih (1997) Adapun faktor-faktor yang mempengaruhi ibu tentang pemberian ASI eksklusif antara lain ibu bekerja, faktor psikologis ibu, takut kehilangan daya tarik sebagai seorang wanita, ibu yang sakit. Hal Ini menunjukkan bahwa ibu-ibu kurang mendapatkan informasi mengenai ASI eksklusif, dan manfaat dari ASI eksklusif tersebut.

Berdasarkan tabel 4 dapat dilihat Proporsi responden yang tidak memberikan ASI Eksklusif lebih banyak pada Responden tingkat pengetahuan rendah yaitu 15 orang $(71,4 \%)$ dibandingkan dengan tingkat pengetahuan tinggi 1 orang $(5,9 \%)$. Berdasarkan analisa data dengan mengunakan uji Chi-Square didapatkan nilai $\mathrm{p}=0,000(\mathrm{p}<0,05)$ ini berarti bahwa ada hubungan antara tingkat pengetahuan dengan pemberian ASI Eksklusif. Hasil Penelitian ini sama dengan yang dilakukan Dewi (2010) bahwa ada hubungan bermakna antara tingkat pengetahuan dengan pemberian ASI Eksklusif. Rendahnya persentase pengetahuan dapat dilihat dari banyak nya responden yang tidak mengetahui tentang pengertian ASI Eksklusif, $56 \%$, manfaat ASI Eksklusif 39\%. Batas waktu pemberian ASI Eksklusif 23\%. dan berapa lama ASI perah dapat disimpan dalam lemari es 31,5 $\%$.

Berdasarkan tabel 5, dapat dilihat bahwa proporsi responden yang tidak memberikan ASI Eksklusif lebih banyak pada ibu yang bekerja sebanyak 9 orang $(69,2 \%)$ dibandingkan dengan ibu yang tidak bekera yaitu 7 orang $(28,0 \%)$. Berdasarkan analisa data dengan mengunakan uji Chi-Square didapatkan nilai $\mathrm{p}=0,036(\mathrm{p}<0,05)$ ini berarti bahwa ada hubungan antara pekerjaan dengan pemberian ASI Eksklusif. Hasil Penelitian ini sama dengan yang dilakukan Dewi (2010) bahwa ada hubungan bermakna antara status ibu bekerja dengan pemberian ASI Eksklusif. $\mathrm{Hal}$ ini sesuai dengan pendapat Soetjiningsih (1997) menyatakan bahwa kecenderungan makin banyak ibu-ibu yang tidak memberikan ASI pada bayinya salah satu penyebabnya adalah banyaknya ibu-ibu yang bekerja terutama di kota-kota besar. Secara teori juga dapat diketahui bahwa faktor-faktor yang mempengaruhi ibu menyusui tidak memberian ASI eksklusif antara lain dikarenakan ibu bekerja, faktor psikologis ibu, takut kehilangan daya tarik sebagai seorang wanita,ibu yang 
sakit. Ketidakhadiran ibu dirumah dalam jangka waktu tertentu untuk bekerja biasanya akan menimbulkan masalah dalam mengatur waktu karena banyaknya jam kerja dan jarak antara tempat bekerja dengan rumah ibu yang jauh sehingga banyak ibu bekerja yang tidak memberikan ASI Eksklusif.

\section{KESIMPULAN}

Berdasarkan hasil penelitian tentang hubungan tingkat pengetahuan dan pekerjaan ibu menyusui dengan pemberian ASI Eksklusif di Kelurahan Simpang Haru Wilayah Kerja Puskesmas Andalas Padang Padang tahun 2017 dapat disimpulkan sebagai berikut:

1. Sebanyak 21 orang $(55,3 \%)$ ibu memiliki tingkat pengetahuan rendah tentang ASI Eksklusif

2. Sebanyak 13 orang $(34,2 \%)$ ibu bekerja di Kelurahan Simpang Haru Wilayah Kerja Puskesmas Andalas Padang.

3. Sebanyak 16 orang $(42,1 \%)$ ibu tidak memberikan ASI Eksklusif

4. Ada hubungan antara tingkat pengetahuan dengan pemberian ASI Eksklusif.

5. Ada hubungan antara ststus pekerjaan dengan pemberian ASI Eksklusif.

\section{UCAPAN TERIKASIH}

Terima kasih kepada Bapak / Ibu pimpinan, ketua UPPM, ketua JIK Akbid dan STIKes Alifah Padang, Pimpinan Puskesmas Andalas Padang, Kader Kelurahan Simpang Haru dan seluruh responden.

\section{DAFTAR PUSTAKA}

Achmadi, 2009. (http://www.Kompas.co.id, Pentingnya pemberian ASI Ekslusif) Di akses tanggal 9 Maret 2017)

Arikunto, Suharsimi (2006). Prosedur Penelitian. Jakarta : Rineka Cipta.

Arir, Nurhaeni (2009). ASI dan Tumbuh Kembang Bayi. Yogyakarta : Media Pressindo.

Arifin,2006.Peningkatan ASI Eksklusif. Angriwijaya jakarta
Dewi, Cici Pristina (2011). "Hubungan Tingkat Pengetahuan dan Sikap Ibu Menyusui dengan Pemberian ASI Eksklusif",

Hegar, Badriul, dkk. (2008). Bedah ASI. Jakarta : Ikatan Dokter Anak Indonesia.

Hasri Meyana, (2009). ASI Eksklusif, Yogyakarta : Graha Medika

Isnaeni (2007). “Hubungan Tingkat Pengetahuan Ibu tentang Pemberian ASI Eksklusif" KTI pada AKBID X Padang.

Jufri, 2004. Kemampuan Intelektual, Jakarta : Numed

Notoatmodjo, Soekidjo (2003). Metodologi penelitian Kesehatan. Jakarta : Rineka Cipta.

(2007). Promosi dan Perilaku Kesehatan. Jakarta : Rineka Cipta.

(2010).

Metodologi penelitian Kesehatan. Jakarta : Rineka Cipta.

Profil Kesehatan Dinas Kesehatan Kota Padang, Tahun 2016

Profil Kesehatan Dinas Kesehatan Kota Padang, Tahun 2017

Purwanti, Hubertin Sri (2004). Konsep Penerapan ASI Eksklusif. Jakarta : EGC

Suradi ,ruliana. 2010. Indonesia menyusui.Jakarta: badan penerbit IDAI

Utami Roesli. 2004. Mengenal ASI Eksklusif. Jakarta : Trubus Agriwidya

.2009.Mengenal ASI Eksklusif. Jakarta : Trubus Agriwidya

Suradi, Rulina dan Roesli, Utami (2008). Manfaat ASI dan Menyusui. Jakarta : FKUI 
Volume 2 Nomor 2 P-ISSN : 2597-8594

Anogara,2006. (http://www.lusa .web.id. ASI Ekslusif , diakses 9 Maret 2017) 